\title{
HUBUNGAN ANTAR AGAMA PADA MASA KERAJAAN USMANI
}

\author{
Lukman Hakim \\ Institut PTIQ Jakarta \\ Email: lukmanhakim@ptiq.ac.id
}

\begin{abstract}
This paper focuses on the concept of religious tolerance in the Ottoman Empire after the conquest of Constantinople by Sultan Muhammad al-Fatih II. This idea had been known as the millet system. The implementation of the millet system under the Ottoman rule was proof that the Ottoman empire had been able to implement religious and cultural harmony. They lived in harmony to make a peace among religions. This paper also attempts to describe a millet system model that had been running for hundreds of years since this concept was created. Co-existence in religious and cultural diversity has been demonstrated by the Ottoman empire in its multicultural and multireligious society. This paper also shows how the millet system can provide benefits if the authorities provide space for recognition to minority groups or people in the territory.
\end{abstract}

Keyword: Non-Muslim, Millet system, Ottoman, communities. 


\section{Pendahuluan}

Penaklukan Kota Konstantinopel dan negeri Balkan merupakan tonggak yang sangat menentukan dalam sejarah Usmani. Selain menguntungkan eksistensi bangsa Turki (Kerajaan Usmani) dan umumya masyarakat Islam, ekspansi wilayah semakin terbuka. ${ }^{1}$ Di sisi lain, Penaklukan Konstantinopel juga berimplikasi pada kemudahaan akses masuknya hegemoni Muslim di bawah kekuasaan Usmani di wilayah-wilayah 'baru'. Sejak penaklukan Konstantinopel ini, Kerajaan Muslim Usmani mendominasi teritorial yang luas di wilayah Asia Minor, Balkan, Timur Tengah dan Afrika Utara. ${ }^{2}$

Wilayah kekuasaan Usmani $^{3}$ sejak abad 15 hingga 16 dianggap sebagai puncak kejayaan. Pada masa Salim 1, luas kekuasaan wilayah Mesir dan Syiria ditaklukkan pada tahun 1516 dan 1517 dan menjadikannya Laut Merah sebagai batas wilayah utara kekuasaan Usmani. Dan pada tahun berikutnya di bawah pemerintahan Sultan al-Qanuni (1520-1566 M), memasuki wilayah-wilayah Kristen Eropa. Pada tahun 1521, ia menaklukkan Belgrade, mengepung Wina tahun 1529. Pada abad berikutnya para sejarawan Usmani menganggap bahwa masa pemerintahan Sultan Sulaiman al-Qanuni sebagai masa ketika sistem kerajaaan berjalan sempurna dan mereka menyebutnya sebagai masa keemasan (golden age) kerajaan Usmani. ${ }^{4}$

\section{Pembahasan}

\section{A. Bizantium dan Penaklukkan Konstantinopel}

Jauh sebelum dikuasai oleh Kerajaan Usmani yang beragama Islam, Byzantium telah lama didiami oleh orang-orang Kristen Ortodoks. Byzantium adalah sebuah kota Yunani kuno, yang menurut legenda, didirikan oleh para warga koloni Yunani dari Megara pada tahun 667 SM dan dinamai menurut nama Raja mereka Byzas atau Byzantas. Nama "Byzantium" merupakan Latinisasi dari nama asli kota tersebut Byzantion. Kota ini kelak menjadi pusat Kekaisaran Byzantium. Kota Byzantium adalah sebuah kota niaga karena lokasinya yang strategis di satusatunya pintu masuk ke Laut Hitam. Pada tahun 330 M, Kaisar Romawi

\footnotetext{
${ }^{1}$ Ira M. Lapidus, A History of Islamic Societies, (Cambridge: Cambridge University Press, 2002), 253

${ }^{2}$ Moshe Ma'os (Ed), The Meeting of Civilization: Muslim, Christian and Jewish, (Sussex Academic Press, 2009), 7

${ }^{3}$ Kerajaan Usmani adalah kerajaan Islam yang didirikan oleh Usman di wilayah bagian barat laut Anatolia (Northwestern Anatolia). Setelah Kekalahan Bizantium, Kerajaan Usmani berpusat di Istanbul (Konstantinopel lama; 1453-1922) Lihat Richard W. Bulliet, dkk, The Earth and Its People: Global History, (Boston: Wadsworth Cengage Learning, 2008), 7

${ }^{4}$ Richard W. Bulliet, dkk, The Earth.. (Boston: Wadsworth Cengage Learning, 2008), . 532
} 
Konstantinus Agung memindahkan ibukota dari Roma ke Bizantium di selat Bosporus ini dan memberi nama baru kota itu "Konstantinopel". Kota ini selanjutnya menjadi ibukota Kekaisaran Romawi Timur, yang kelak disebut kekaisaran Byzantium. ${ }^{5}$ Kombinasi imperialisme dan lokasi ini mempengaruhi peran Konstantinopel sebagai titik-penyeberangan antara dua benua: Eropa dan Asia. Kota ini merupakan sebuah magnet komersial, kultural, dan diplomatik. Dengan letak strategisnya itu, Konstantinopel mampu mengendalikan rute antara Asia dan Eropa, serta pelayaran dari dari Laut Mediterania ke Laut Hitam.

Kaisar Konstantinus berkuasa sejak 306 sampai dengan 370 M. dan sebagai kaisar Timur dan Barat, Konstantinus memperbaiki struktur kekaisaran. Ia memberikan status baru kepada para uskup, setara dengan senator. Secara teori, gereja dan negara menjadi satu meskipun perpecahan dan percekcokan tetap berlangsung, baik di dalam gereja maupun gereja dan negara. Walaupun mendukung kristianitas, Konstantinus tidak membuatnya menjadi agama resmi negara, namun ia memberi hadiah, sumbangan, dan tanah kepada gereja Kristen dan membangun beberapa Basilika. Begitu pula menggunakan simbol kristen pada uang logam dan bendera Romawi. Baru pada tahun 380 M, Flavius Theodosius (m.379-395) seorang Kristen Ortodoks, menetapkan Kristianitas sebagai agama resmi negara itu. Selanjutnya, sejak diberlakukan sebagai agama resmi negara oleh Theodosius, orang-orang Kristen menjadi kelompok mayoritas. Para misionaris melanjutkan mendirikan Gereja-Gereja dan mengajarkan iman Kristen dalam bahasa Yunani dan Latin. ${ }^{6}$ Di sisi lain, keberadaan uskup menjadi lebih agung. Uskup Roma "pontifex Maximus"- imam besar yang bukan hanya memiliki kekuasaan spiritual tetapi juga politik. Kesejahteraan gereja disatukan ke dalam kesejahteraan agama, yang berarti musuh negara adalah musuh gereja juga. Sedangkan musuhnya adalah mereka yang non-Romawi dan non-kristiani. ${ }^{7}$

Pada abad ke-8, benih-benih perpecahan antara gereja Timur dan Barat mulai terjadi. Bibit perpecahan ini umumnya disebabkan oleh klaim kekuasaan, pengaruh, dan kekayaan (tanah) yang sudah sangat mewarnai hidup gereja waktu itu. Bibit perpecahan ini juga diperparah dengan persoalan ikonaklasme. Ikonaklasme adalah semangat sekelompok umat religius di Timur yang menentang pemujaan terhadap ikon (gambar, patung kudus). Paus (Gereja Barat) tidak

\footnotetext{
${ }^{5}$ Lihat Gerald O'Collin \& Edward G. Farrugia, SJ., Kamus Teologi (Yogyakarta: Penerbit Kanisius, 1996), . 103

${ }^{6}$ Michael Collins \& Matthew A. Price, The Story of Christianity: Menelusuri Jejak Kristianitas (Yogyakarta: Penerbit Kanisius, 2006 ), . 59

${ }^{7}$ Paul F. Knitter, Pengantar Teologi Agama-Agama, (Yogyakarta: Penerbit Kanisius, 2008), . 75-76
} 
mempersoalkan penghormatan kepada ikon, gambar atau patung suci, sedangkan Kaisar yang selalu ditaati oleh gereja Timur sangat menentang penghormatan ikon itu. ${ }^{8}$

Pada awal abad ke-11, perbedaan budaya mulai tampak antara Timur dan Barat menimbulkan masalah. Timur mengizinkan tradisi helenistik yang memungkinkan orang tidak bisa lagi berbahasa Latin. Di daerah barat, hanya sedikit orang yang bisa bahasa Yunani. Timur mulai memandang barat tidak berpendidikan dan tidak beradab. Di Timur, tingkat pendidikan di antara kaum awam memang tinggi, seperti para imam. Sedangkan di Barat hanya terbatas bagi elite Gereja. Dan Timur dan Barat telah jauh terpisah secara politis. Hingga akhirnya perpecahan ini resmi terjadi ketika Paus Leo IX (1049-1054) mencetuskan perpecahan dengan Konstantinopel dengan menegaskan otoritas spiritualnya, dengan menyelenggarakan sinode untuk memperbarui Gereja Sisilia dan menunjuk Uskup Agung yang baru untuk Sisilia dan membuat Patriach Konstantinopel berang. ${ }^{9}$ Jarak antara Gereja barat dan Gereja Timur semakin lebar, kemudian gereja belahan Timur dikenal sebagai gereja Ortodoks dan gereja di belahan Barat dikenal sebagai Gereja Katolik. ${ }^{10}$ Dalam perkembangannya, konflik antara Gereja Barat dan Timur menciptakan jurang pemisah. Sikap paus dan para ksatria Eropa Barat sangat menyakiti perasaaan Gereja Ortodoks Timur sebab mereka mendirikan organisasi Gereja Latin. Bahkan hal yang paling parah adalah ketika tentara perang Salib keempat menduduki kota Konstantinopel. ${ }^{11}$

Pertikaian antara Gereja Barat dan Timur juga ikut mempercepat kemunduran kekaisaran Byzantium. ${ }^{12}$ Pada tanggal 29 Mei 1453, kota ini jatuh ke tangan Kerajaan Usmani. Dengan jatuhnya Konstantinopel ke tangan Kerajaan Usmani, maka ibukota pemerintahan Kerajaan ini kemudian dipindah ke kota ini. Bangsa Turki menyebut kota ini Istanbul. Dengan demikian maka pemerintahan di Kota ini beralih dari pemerintahan orang-orang Kristen menjadi pemerintahan orang Muslim yaitu Kerajaan Usmani.

\section{B. Kebangkitan Kerajaan Usmani}

\footnotetext{
${ }^{8}$ Yosep Lalu, Pr., Menggumuli Makna Hidup dalam Terang Iman Katolik: Seri 4, (Yogyakarta: Penerbit Kanisius, 2010), . 19

9 Yosep Lalu, Pr., Menggumuli . 20

${ }^{10}$ Yosep Lalu, Pr., Menggumuli . . 21

11 Th. Van Den End \& Christiaan de Jonge, Sejarah Perjumpaan Gereja dan Islam, (Yogyakarta: Penerbit Kanisius, 2010), . 82

12 Th. Van Den End \& Christiaan de Jonge, Sejarah . . 82
} 
Kerajaan Usmani muncul sebagai pemimpin salah satu kelompok pejuang Turkmenistan yang beroperasi di wilayah perbatasan antara Bizantium dan Seljuk di Anatolia pada abad ke-13. Mereka datang ke wilayah ini karena menghindar dari tekanan bangsa Mongol di Asia Tengah serta mencari tanah baru dan peluang ekonomi yang lebih baik. Orang-orang Seljuk sebagai penguasa sebelumnya; Bani Umayyah dan Bani Abbasiyah telah bangkit di wilayah ini melawan orang-orang Bizantium dengan alasan-alasan agama yang menguntungkan mereka. Mereka kemudian dikenal sebagai gazi (pejuang agama). Dalam perkembangannya, para pemimpin gazi yang sukses dapat menarik banyak pengikut dan bergelar $u c$ beyi atau march bey. Sebagian dari mereka yang berkembang, berhasil membuat kerajaannya sendiri, tak terkecuali kerajaan Usmani. ${ }^{13}$

Berawal dari sebuah kelompok Turki berjumlah 400 orang dengan 44 penunggang kuda bergerak menuju ke arah barat dari hulu sungat Eufrat. Nama pemimpin mereka adalah Ertogrul, saat mereka berjalan melalui Asia Kecil, mereka melihat perang dengan jumlah yang tidak sebanding. Tanpa mengetahui siapa kombatannya, Ertogrul dan pasukan langsung mengambil keputusan untuk membantu yang lemah dan menyerang hingga akhirnya mengalami kemenangan bersama prajuritnya. Dari sinilah nama Usmani muncul, dimana putra Ertogrul bernama Usman kelak berhasil mendirikan kerajaan sehingga nama kerajaan dinisbahkan kepada namanya; Usman. ${ }^{14}$

Kerajaan Usmani muncul setelah keruntuhan Kerajaan Abbasiyah di Baghdad pada tahun 1250. Kerajaan Usmani didirikan oleh Usman sekitar akhir abad ke 13 di Anatolia di atas reruntuhan Kerajaan Seljuk. Sebelum menaklukkan Byzantium pada tahun 1453, Kerajaan Usmani hanyalah sebuah kerajaan kecil di daerah perbatasan yang sering terlibat dalam peperangan. Pada tahun 1326, Bursa menjadi Ibu kota Kerajaan Usmani kemudian sekitar tahun 1366 kerajaan Usmani dipindahkan ke Adrianopel. Kemudian sejak konstantinopel jatuh ke tangan Usmani pada tahun 1453, kota ini langsung menjadi ibukota baru sekaligus mengantarkan Kerajaan ini pada satu era baru yaitu era kerajaan besar. ${ }^{15}$ Ibukota ini kemudian diubah nama menjadi Istanbul.

\footnotetext{
${ }^{13}$ Mark. L. Stein, Guarding The Frontier: Ottoman Bordier Forts and Garrison in Europe (London: Tauris Academic Studies, 2007)

${ }^{14}$ Sir Edward S. Creasy, The Ottoman Turks; From the Beginning of Their Empire to the Present Time (New York: Henry Holt and Company, 1878), 1

${ }^{15}$ Philip K. Hitti, History of The Arabs, (Jakarta: Serambi, 2006), .906
} 
Dari sisi durasi dan luas wilayah kekuasaan, tak satu pun kerajaan Islam yang bisa menandingi Kerajaan Usmani (1290 M- 1922 M). ${ }^{16}$ Selama masa kekuasaannya, Kerajaan Usmani pernah melalui beberapa proses islamisasi dan modernisasi. ${ }^{17}$ Ketika Timur Lank menaklukkan Turki di Ankara (1402 M), negara yang masih hijau itu terpecah belah. Dibutuhkan perjuangan yang sangat keras untuk mempersatukan kembali Rumelia dan Anatolia di bawah Muhammad I (m. 1413-1421 M). Setelah itu, dimulailah zaman keemasan ekspansi, pengembangan, kebebasan dan pembangunan negara yang dilakukan oleh beberapa sultan yang cakap. Secara berurutan, Muhammad II, Bayazid II, Salim I dan Sulaiman I, memerintah selama lebih dari 120 tahun. ${ }^{18}$

Pada masa pemerintahanan empat Sultan di atas, Kerajaan Usmani menjelma menjadi sebuah kerajaan besar yang ditakuti lawan dan disegani kawan. Salah satu point keberhasilan Kerajaan ini adalah membangun hubungan yang harmonis antara penguasa baru (Kerajaan Usmani muslim) ini dengan seluruh komponen masyarakat non-muslim yang diatur dalam undang-undang dan kemudian menjadi pedoman bagi sultan sesudah mereka. Dengan kata lain, kerukunan umat beragama atau toleransi antar umat beragama menjadi faktor penting dalam membangun sebuah pemerintahan yang ideal.

Peran serta pemerintahan dalam rangka membangun kesadaran hidup majemuk yang multi agama, etnis dan kultur berkembang setiap masa sangatlah penting. Dalam Islam, pertemuan agama-agama sudah terjadi sejak kemunculan Islam itu sendiri. Lebih dari seribu tahun umat Islam dan umat Kristiani telah mencoba gagasan kerukunan hidup antara umat beragama berdasarkan kepercayaan mereka masing-masing. Sejak masa pertengahan, dialog-dialog antar agama yang pertama dalam sejarah telah mulai dilakukan di istana-istana para penguasa Muslim di Baghdad dan Andalusia. Tetapi saling pengertian dan timbal balik tidak berkembang sebagaimana diharapkan karena adanya prasangka-

\footnotetext{
${ }^{16}$ Kerajaan Usmani adalah sebuah kesultanan yang berpusat di Istanbul. Kerajaan ini merupakan salah satu dari tiga kerajaan besar - yang muncul pada abad pertengahan di samping Kerajaan Safawi dan Kerajaan Mogul-pasca keruntuhan Kerajaan Abbasiyah di Baghdad. Kerajaan ini didirikan oleh Usman putra Artogol dari Kabilah Oghuz di daerah Mongol. Awalnya mereka datang ke Turki untuk meminta perlindungan kepada penguasa Seljuk dari serangan orang-orang Mongol. Mereka juga membantu Sultan Alauddin II berperang melawan Bizantium. Usman lalu dipercaya menjadi panglima perang Kerajaan Seljuk, menggantikan ayahnya. Setelah Sultan Alauddin wafat, Usman mengambil alih kekuasaan dan sejak itulah berdiri kerajaan Usmani; diambil dari namanya.

${ }^{17}$ Antony Black, The History of Islamic Political Thought: From the Prophet to Present, cet.2 (Edinburgh: Edinburgh University Press, 2011 ), 197

${ }^{18}$ Antony Black, The History ..., 199.
} 
prasangka dari masing-masing pihak dan situasi politik yang tidak menguntungkan. 19

\section{Heterogenitas Kerajaan Usmani}

Pasca penaklukkan Konstantinopel oleh Sultan Muhammad al-Fatih pada tahun 1453, Kerajaan Usmani memasuki babak baru pemerintahan yang lebih mapan. Menurut Stanford J. Shaw, kekuasaan Usmani semakin meluas dari Danube Eropa Tengah hingga memasuki Timur Tengah dan Afrika Utara. ${ }^{20}$ Pada masa puncak kejayaannya, berturut-turut beberapa wilayah masuk ke dalam genggamannya; Asia Kecil, Balkan, Timur Tengah, Afrika Utara dan menurut Anthony Black luas wilayah kekuasaan Kerajaan Usmani mulai dari daerah-daerah pinggiran Atlantik hingga sungat Eufrat, dari padang Safana (Rusia) hingga Sahara (Arab) meliputi beberapa wilayah timur tengah seperti Hijaz dan Syiria raya; Suriah, Palestina dan Mesir. ${ }^{21}$

Selain wilayah kekuasaan yang begitu luas, Kerajaan Usmani juga meliputi ras, budaya dan agama yang beragam. Beberapa wilayah yang sebelumnya masuk ke dalam kekuasaan Bizantium, lambat laun lepas ke tangan Usmani seperti kawasan-kawasan di sekitar Eropa Timur; Thrace, Makedonia, Bulgaria, Serbia dan Bosnia. ${ }^{22}$ Di puncak kejayaan Usmani pada abad ke-16, Usmani menjadi penguasa atas ras-ras yang beragam mulai dari Eropa, Asia dan Afrika; seperti bangsa Arab, Suriah, Irak, Mesir, Berber, Kurdi, Armenia, Slavia, Yunani dan Albania. Dari total bangsa yang dikuasai oleh Kerajaan Usmani, menurut Philip K. Hitti, kelompok Turki hanyalah kelompok kecil saja dari wilayah kekuasan yang sangat besar. $^{23}$

\section{Dar al-Islam dan Dar al-Harb dalam Kerajaan Usmani}

Dalam sistem pemerintahan Islam khususnya kerajaan Usmani, masyarakat terbagi dari kelompok yaitu muslim, dzimmi (non-muslim yang berada dalam lindungan penguasa muslim), dan kafir. Dalam bukunya, Abdullahi an-Naim menyebutkan bahwa sistem dzimmi tradisional sebetulnya dikembangkan oleh para ulama sebagai bagian dari sebuah pandangan yang menentukan afiliasi politik

\footnotetext{
${ }^{19}$ Elza Peldi TaherTa (Ed), Merayakan Kebebasan Beragama; Bunga Rampai 70 Tahun Djohan Effendi, (Bandung: Mizan, ), . 13

20 Stanford J. Shaw, History of the Ottoman Empire and Modern Turkey (Cambridge: Cambridge University, 1976), 55.

${ }^{21}$ Antony Black, The History 199.

${ }^{22}$ Antony Black, The History, 199.

${ }^{23}$ Lihat Philip K. Hitti, History of The Arabs, (Jakarta: Serambi, 2006), 913.
} 
berdasarkan afiliasi keagamaan dan bukan berdasarkan wilayah negara seperti yang terjadi pada saat ini. ${ }^{24}$ Sistem ini, mengandaikan adanya perbedaan tegas antara wilayah Islam (dar al-Islam) tempat di mana Muslim berkuasa dan syariah berlaku, dengan wilayah yang penduduknya memerangi Muslim (dar al-harb). Dengan sistem seperti maka visi yang dibangun bahwa kewajiban untuk menyebarkan Islam dengan cara damai maupun perang tetap berlaku sampai seluruh dunia menjadi dar al-islam. Pandangan seperti ini kemudian menandai kesuksesan umat Islam dalam menaklukkan berbagai daerah sejak dari Afrika Selatan sampai Spanyol bagian selatan di Barat, Persia, Asia Tengah, dan India bagian utara di Timur setelah Rasulullah meninggal. Kemudian dalam perjalanan pemerintahan Islam, keterbatasan dan ketidakpastian ekspansi membuat penguasa Muslim harus menandatangani kesepakatan damai (sulh) dengan orang-orang kafir, yang oleh ulama diakui legitimasinya, sehingga wilayah tempat mereka tinggal dianggap wilayah yang mempunyai kesepakatan damai dengan umat Islam (dar al-sulh). ${ }^{25}$

Berdasarkan model relasi non-Muslim yang dikembangkan selama abad ke 7 dan 8, Syariah mengklasifikasi manusia pada tiga kategori yaitu Muslim, ahl alkitab (umat yang juga menerima pewahyuan kitab suci seperti Kristen dan Yahudi) dan kafir. Adapun skema dasar yang menyatakan bahwa hanya Muslim-lah yang berhak menjadi anggota penuh komunitas politik, sedangkan ahl al-kitab sebagai anggota tidak penuh, tetap tidak bisa diubah atau dimodifikasi menurut pandangan syariah. Sedangkan orang kafir sama sekali tidak memiliki kualifikasi untuk mendapatkan pengakuan hukum atau perlindungan seperti itu, kecuali mereka mendapat jaminan perlindungan temporer (aman) karena alasan-alasan praktis seperti dalam rangka perniagaan dan diplomasi. ${ }^{26}$

Istilah dzimmah merujuk pada perjanjian yang dibuat antara negara yang dipimpin oleh Muslim dengan komunitas ahl al-kitab agar mereka mendapat jaminan keamanan atas diri dan hartanya, kebebasan untuk melakukan kewajiban agamanya dengan otonomi komunal dan privat untuk mengelola urusan-urusan internalnya dan sebagai balasannya mereka (ahl al-kitab) harus membayar pajak yang disebut jizyah dan mematuhi perjanjian yang mereka buat dengan negara. ${ }^{27}$

\footnotetext{
${ }^{24}$ Lihat Abdullahi Ahmed an-Na'im, Islam dan Negara Sekuler; Menegosiasikan Masa Depan Syariah, (Bandung: Mizan, 2007), . 200

25 Abdullahi Ahmed an-Na'im, Islam. 201

26 Abdullahi Ahmed an-Na'im, Islam . 201

27 Lihat Abdullahi Ahmed an-Na'im, Islam ..., . 201. Tradisi toleransi beragama sudah dicontohkan oleh Rasulullah Saw yang disebut Piagam Madinah; yang dianggap sebagai konstitusi negara tertulis pertama di dunia, mendahului Magna Carta di Inggris selama enam abad dan Konstitusi Amerika Serikat dan Perancis selama 12 abad. Piagam Madinah ini ditetapkan pada tahun 622 M (1 Hijriyah). Hingga akhir hayatnya, Rasulullah Saw telah melakukan interaksi intensif dengan seluruh kelompok agama
} 
Sistem hukum Kerajaan Usmani merupakan sistem yang tidak terpusat, majemuk dan dinamis untuk menghadapi perbedaan agama, etnis dan kultural warga negaranya. Berdasarkan tradisi hukum yang berlaku pada Kerajaan Islam sebelumnya, Kerajaan Usmani mengembangkan sistem hukum (Kanun alOsmani) yang berisi tiga bagian: (1) Syariah; (2) undang-undang (termasuk hukum adat-orf); dan (3) aturan hukum minoritas yang berlaku bagi non-Muslim. ${ }^{28}$

Prinsip syariah yang dianut kerajaan Usmani adalah prinsip Madzhab Hanafi, sementara itu pengadilan (termasuk pula para hakim) adalah institusi resmi yang beroperasi di bawah otoritas pemerintahan pusat di Istanbul. Sedangkan kedua adalah kanun yang merupakan undang-undang yang ditetapkan oleh Sultan dalam posisinya sebagai khalifah. Kanun ini biasanya diambil dari adat istiadat, dan kemungkinan bisa berbeda-beda antara satu daerah dengan daerah lainnya. Ketetapan Sultan ini biasanya tidak tercakup dalam prinsip-prinsip syariah seperti struktur institusi negara, pemberlakuan pajak (selain yang ditentukan oleh syariah), hukuman-hukuman tertentu. ${ }^{29}$ Adapun kanun pertama kali disistematisasi oleh Sultan Muhammad Al-Fatih dan kemudian oleh Sultan Sulaiman al-Qanuni yang dikenal sebagai 'kanuni' karena usahanya untuk melakukan penyusunan ini. Bagian ketiga dari sistem hukum kerajaan Usmani adalah hukum dan administrasi peradilan komunitas non-Muslim (Millet). Untuk poin ketiga ini membahas segala aspek terkait dengan kelahiran, pernikahan, perceraian, kematian berdasarkan hukum adat dan agama mereka masing-masing. Hukum adat dan agama mereka juga berlaku dalam urusan-urusan yang lebih luas seperti dalam hubungan ekonomi dan sosial. Komunitas gereja bisa mengadili dan menjatuhkan hukuman penjara pada pelanggar hukum dan menyerahkan proses eksekusi hukum mereka kepada otoritas Kerajaan Usmani. Sekalipun demikian otonomi hukum masyarakat nonMuslim memiliki batasan yang cukup penting dan kebijakan Sultan tetap berada diatasnya. Sultan berhak menunjuk atau memecat pemimpin sebuah komunitas Millet. ${ }^{30}$

Kemajuan Usmani pada abad ke 15 menyerupai ekspansi awal Islam delapan abad sebelumnya. Kelompok Ahli kitab kembali memperoleh toleransi. Dalam

\footnotetext{
(pagan, Yahudi, Kristen), budaya-budaya dominan dan kekuatan-kekuatan politik terbesar ketika itu seperti Persia dan Romawi. Prestasi Rasulullah ini kemudian diikuti oleh Umar bin Khattab yang pada tahun $636 \mathrm{M}$ menandatangani perjanjian Aelia dengan umat Kristen di Jerussalem. Sebagai pihak yang menang perang, Umar tidak menerapkan politik pembantaian terhadap pihak Kristen. Lihat dalam Adian Husaini, Piagam Madinah dan Toleransi Beragama. http://www.insistnet.com,

${ }_{28}$ Abdullahi Ahmed an-Na'im, Islam. 354

${ }^{29}$ Abdullahi Ahmed an-Na'im, Islam. 355

${ }^{30}$ Abdullahi Ahmed an-Na'im, Islam. 356
} 
beberapa bulan setelah jatuhnya Konstantinopel, sebuah perjanjian disepakati antara Sultan dan Patriat Gennadios. Kekuasaan Usmani akan melindungi pembangunan gereja Yunani - bahkan untuk melawan musuh mereka sesama Kristen seperti Gereja Ortodoks Serbia. Patriat akan menjamin kesetiaan dengan Usmani dan dengan musuh-musuh Katolik sang Patriat sendiri. Secara pribadi, Patriat mungkin mengartikan bangsa Turki sebagai "Anjing berdarah dari kaum Hajariyyin". Dalam prakteknya, perjanjian yang ada terbukti sama-sama nyaman bagi kedua meskipun tetap ada masa yang berat. Di Ibukota, gereja-gereja Yunani dan orang-orang menyebar. Sebagaimana ditulis Fletcher, hampir selama masa pemerintahan Usmani, hingga awal abad ke 20, penduduk Konstantinopel (Istanbul) terbagi dalam proporsi 60 persen Muslim dan 40 persen umat Kristen dan Yahudi. Dan Konstantinopel tidak pernah menjadi kota Islam secara demografis dalam pengertian misalnya seperti Baghdad. ${ }^{31}$

Dalam masalah keberagamaan, anggota komunitas dzimmi harus berpakaian dengan cara berbeda, membayar jizyah; dan hidup dalam lingkungan terpisah, terutama di dalam kota. Namun, dalam praktiknya, aturan-aturan ini tidak dilaksanakan secara ketat. Banyak orang Kristen dan Yahudi menduduki jabatan tinggi dan posisi yang cukup sensitif, misalnya duta besar dan gubernur, terbebas dari kewajiban jizyah, dan memakai pakaian tertentu. ${ }^{32}$

Secara formal, komunitas Kristen dan Yahudi harus tunduk pada beberapa batasan simbolik lain, misalnya larangan untuk menyelenggarakan ritual keagamaan secara publik dan membangun rumah di wilayah Muslim. Pembatasan ini dilakukan untuk menandakan rendahnya status komunitas dan anggota dzimmah. Namun, beberapa aturan administratif yang diberlakukan imperium Ustmani seperti relokasi beberapa komunitas Kristen dan Yahudi dari beberapa provinsi ke Istanbul, dan pembatasan tempat tinggal mereka di wilayah-wilayah tertenut lebih dimotivasi oleh kepentingan ekonomi negara akibat kondisi sosial tertentu. Relokasi paksa diberlakukan sebagai hukuman individual dan komunal. ${ }^{33}$ Begitu pun keharusan memakai jenis pakaian tertentu dan membawa tanda identitas khusus. Aturan ini merupakan kebijakan umum imperium Usmani yang diberlakukan untuk mengklasifikasikan warga negara berdasarkan kelas sosial,

\footnotetext{
${ }^{31}$ Lihat Richard Fletcher, Relasi Damai Islam dan Kristen, terj dari The Cross and The Crescent (Tangerang: Pustaka Alvabet, 2009), . 152

32 Abdullahi Ahmed an-Na'im, Islam. 352

${ }^{33}$ Abdullahi Ahmed an-Na'im, Islam. 354
} 
profesi, dan identitas etnis keagamaan, yang tidak hanya berlaku bagi penduduk yang berstatus dzimmi saja. $^{34}$

\section{E. Perkembangan Millet System}

Sejak awal pemerintahan Kerajaan Usmani di Istanbul, hubungan antara muslim dan non-muslim sudah berjalan dengan baik. Orang-orang Kristen dan Yahudi menjalankan ibadahnya di tempat-tempat ibadah mereka di gereja atau sinagog dan mengajarkan agama mereka di sekolah mereka masing-masing dan seminari. Di antara mereka menjalankan urusan bisnis (duniawi) dengan baik. Dalam pemerintahan Usmani, proses toleransi berjalan sangat unik.

Menurut Imber, pada masa kekuasaan Usmani, populasi kerajaan sangat beragam dalam hal agama, bahasa dan struktur sosial. Sebagai pemimpin (Sultan) yang berkuasa, Islam menjadi agama yang dominan, tetapi gereja Ortodok Yunani dan Armenia tetap memiliki peran penting bagi struktur politik kesultanan dan melayani populasi kristen yang besar di banyak daerah yang mengalahkan jumlah orang-orang Islam. Selain Kristen, terdapat pula orang-orang Yahudi di wilayah Usmani. Setelah mereka diusir dari Spanyol pada tahun 1492, Tessaloniki menjadi tempat dengan populasi Yahudi terbesar di dunia saat itu. Ada pula kelompok agama lain seperti kaum Maronit dan Druze dari Libanon. ${ }^{35}$

Sistem millet ini mengacu pada praktik Kerajaan yang membagi orang berdasarkan komunitas yang diakui antara abad ke-15 dan awal abad ke-20. Pada awal abad ke-19, sistem millet yang didasarkan pada praktik ini telah menjadi tulang punggung organisasi hukum dan kemasyarakatan Kerajaan Usmani. Intinya, di bawah naungan Usmani, warga dikategorikan ke dalam komunitas agama. ${ }^{36}$

\section{Kristen}

Kristen adalah kelompok terbesar kedua setelah Muslim khususnya di pusat Ibu kota Kerajaan Usmani. Di bawah kerajaan Usmani, mereka hidup berdampingan dengan komunitas lain. Hubungan internal dan eksternal komunitas dzimmi diatur oleh pemimpinnya, tapi harus tetap tunduk pada aturan kerajaan Usmani. Komunitas-komunitas terpisahkan oleh perbedaan agama dan sekte. Orang Armenia penganut Gregorian, orang Kristen Protestan dan Katolik dianggap

\footnotetext{
${ }^{34}$ Abdullahi Ahmed an-Na'im, Islam. 352

35 Collin Imber, The Ottoman Empire 1300-1650; the Structure of Power, (New York: Palgrave MacMillan, 2002), 252

${ }^{36}$ Emrah Sahin, Ottoman Institution, Millet System: 1250 to 1920 dalam Andrea (Ed), Cultural Sociology of the Middle East, Asia \& Africa: An Encyclopedia (Thousand Oaks: SAGE Publication Inc, 2012), 2
} 
sebagai komunitas agama yang berbeda dan tinggal di lingkungan yang terpisah dengan gereja dan sekolahnya masing-masing serta berdasarkan pada yuridiksi hukum agama masing-masing. ${ }^{37}$

Gereja Ortodoks Yunani mendapatkan otonomi dan prestise tertinggi dalam struktur Millet. Mereka memiliki keuskupan pusat di Istanbul yang menjadi pusat keagamaan, hukum, dan keuangan bagi seluruh komunitas Yunani di seluruh wilayah kesultanan. Dewan Sinode keuskupan yang terdiri dari uskup agung dan pendeta-pendeta utama memiliki kontrol atas urusan-urusan agama dan umum termasuk melakukan sensor terhadap buku-buku berbahasa Yunani. Keuskupan Kristen Armenia juga mendapatkan otonom yang cukup signifikan, meski tak sama dengan keuskupan Yunani dalam urusan-urusan keagamaan, administratif dan hukum komunitasnya. ${ }^{38}$

Adapun di wilayah Arab, penduduk Arab telah didominasi oleh Muslim sejak sekitar abad ke-10. Sebelum Islam, sebagai bagian dari kekaisaran Bizantium, Mesir dan pesisir Mediterania Timur memberikan banyak orang Kristen selama berabad-abad setelah Kaisar Konstantinus (M. 306-337 M) saat Bizantium menjadikan agama ini sebagai agama resmi kerajaan. Pasca konsili Calcedon pada tahun 451, kristen mengalami gelombang perpecahan. Orang-orang Mesir yang kemudian dikenal sebagai kristen koptik menderita penganiayaan dari Bizantium.

Pada masa Usmani, orang-orang Kristen memainkan peranan penting dalam perdagangan di dalam dan di antara propinsi-propinsi Arab. Selain itu, orang-orang Armenia juga aktif dalam perdagangan darat dengan Iran dan India.

Saat Usmani menaklukkan tanah Arab pada tahun 1516-1517 sebagian besar penduduk Yahudi di wilayah Arab adalah penutur bahasa Arab. Selama tahuntahun ini, tanah Arab juga menjadi tujuan wilayah alternatif orang-orang Yahudi yang terusir dari Spanyol setelah Granada jatuh ke tangan Kristen Katolik dan reunifikasi Spanyol di bawah pemerintahan kristen pada tahun $1492 .{ }^{39}$

\section{Yahudi}

Adapun terkait dengan agama Yahudi, dalam sejarahnya yang panjang, yakni sekitar 633 tahun (1289-1922), Kerajaan Usmani mencatat sejarah yang manis dalam hal perlindungan terhadap Yahudi. Selama lebih dari 500 tahun, Kerajaan Usmani menjadi ‘surga' bagi pengungsian kaum Yahudi yang diusir dan

\footnotetext{
${ }^{37}$ Abdullahi Ahmed an-Na'im, Islam. 352

${ }^{38}$ Abdullahi Ahmed an-Na'im, Islam. 353. Lihat juga dalam Bruce Masters, Christian and Jews in the Ottoman Arab World, (Cambridge: Cambridge University Press, 2001), . 1-16

39 Jane Hathaway, Arab Land Under Ottoman Rule 1516-1800 (Oxon: Routledge, 2020), ...
} 
dibantai oleh kaum Kristen Eropa. ${ }^{40}$ Kaum Yahudi di wilayah Usmani merasakan hidup di tanah air mereka sendiri. Selama ratusan tahun mereka tinggal di sana, menikmati kebebasan beragama, dan berbagai perlindungan sebagai minoritas dengan status ahlu dzimmah. Selama itu, kaum Yahudi tidak berpikir untuk memisahkan diri dari Kerajaan Usmani. Sebagai contoh pada masa pemerintahan Sultan Sulaiman al-Qanuni (1520-1566) di Jerussalem, Yahudi hidup berdampingan dengan kaum muslim. Sejumlah pengunjung Yahudi tercengang dengan kebebasan yang dinikmati kaum Yahudi di Palestina. Pada tahun 1535, David dei Rossi, seorang Yahudi Italia, mencatat bahwa di wilayah Kerajaan Usmani, kaum Yahudi bahkan memegang posisi-posisi pemerintahan dan ini adalah suatu hal yang mustahil terjadi di Eropa. David menyatakan, "Here we are not in exile, as in our own country (kami di sini bukanlah hidup di buangan, tetapi layaknya di negara kami sendiri). ${ }^{41}$

Umat Yahudi merupakan bagian yang penting dalam sistem Millet Kerajaan Usmani, apalagi setelah populasi mereka bertambah banyak karena gelombang imigrasi dari Hongaria (1376), Perancis (1394), serta Spanyol dan Italia pada abad ke-15. Mereka tidak punya struktur keuskupan seperti umat Kristiani, dan posisi Rabi Agung di Istanbul pun tidak pernah terisi hingga tahun 1835. Walaupun semua komunitas Yahudi dianggap sebagai satu Millet, umat Yahudi sendiri mengorganisasikan diri dalam komunitas-komunitas (kahals) berbeda; bergantung pada asal dan afiliasi kultural mereka. Masing-masing kahal ini memiliki hubungan tersendiri dengan Kerajaan Usmani dan bertanggung jawab untuk mengumpulkan pajak, menyerahkan bagian tertentu kepada kas negara, menggunakan uang untuk kegiatan komunitas, mengatur pelayanan makanan (kosher), dan menghukum pembangkang. Setiap komunitas Yahudi memiliki Sinagoge, Rabbi, guru, sekolah, rumah sakit, dan pemakaman masing-masing. Banyak di antara lembaga sosial ini memiliki dewan hakim yang disebut Bet Din yaitu seorang rabi yang dipilih oleh komunitasnya. ${ }^{42}$

Perlindungan Kerajaan Usmani terhadap umat Yahudi juga sangat baik. Ketika orang-orang Yahudi menjadi sasaran kebencian dan penindasan di wilayah Kristen Eropa, wilayah-wilayah Muslim menjadi tempat yang aman bagi Yahudi. Meskipun memberikan gambaran yang tidak terlalu tepat terhadap perkembangan Islam, Encyclopedia Judaica masih mengakui bahwa sikap muslim terhadap

\footnotetext{
${ }^{40}$ Adian Husaini, Tinjauan Historis Konflik Yahudi Kristen Islam, (Jakarta: Gema Insani Press, 2004), . 92-93

${ }^{41}$ Adian Husaini, Tinjauan 162

${ }^{42}$ Abdullahi Ahmed an-Na'im, Islam. 353
} 
Yahudi jauh lebih toleran dibandingkan sikap Kristen. Since Islam spread by force or arms rather than by spiritual propaganda, it didn't generally aspire, at least initially, to conquer souls. Therefore, it displayed greater tolerance than Christianity. Meskipun Islam disebarkan dengan kekuatan atau senjata lebih dari pada dengan propaganda spiritual, islam tidak bermaksud -setidaknya pada tahap awal - untuk menaklukkan jiwa (memaksa perpindahan agama). Karena itu Islam memperlihatkan sikap yang jauh lebih toleran dibandingkan Kristen." 43

Ketika orang-orang Yahudi mengalami berbagai tindak kekejaman di Eropa, kaum Yahudi di wilayah Usmani merasakan hidup di tanah air mereka sendiri. Selama ratusan tahun mereka tinggal di sana, menikmati kebebasan beragama, dan berbagai perlindungan sebagai kaum minoritas dengan status sebagai ahlu dhimmah. Selama itu kaum Yahudi tidak berpikir untuk memisahkan diri dari Usmani. Sebagai contoh, di Yerussalem, di masa pemerintahan Sultan Sulaiman Agung (1520-1566), Yahudi hidup berdampingan dengan kaum muslim. Sejumlah pengunjung Yahudi dari Eropa sangat tercengang dengan kebebasan yang dinikmati kaum Yahudi di Palestina. Pada tahun 1535, David dei Rossi, seorang Yahudi Italia, mencatat di wilayah Usmani, kaum Yahudi bahkan memegang posisi-posisi di pemerintahan, sesuatu yang mustahil terjadi di Eropa. Ia mencatat, "Here we are not in exile, as in our own country. Kami di sini bukanlah hidup di buangan, tetapi layaknya di negeri kami sendiri. ${ }^{44}$

Epstein menyebutkan bahwa selama abad ke-15, ketika Usmani sedang berjuang mengukuhkan kekuasaannya di Balkan, terdapat kekacauan yang luar biasa di antara komunitas Yahudi di Eropa tengah dan Eropa barat. Wilayahwilayah Usmani kemudian memikat orang-orang Yahudi terutama untuk pindah terutama saat terjadi pengusiran besar-besaran terhadap umat Islam dan Yahudi di Andalusia. Banyak orang Yahudi yang hengkang menuju wilayah-wilayah Usmani. Kehadiran mereka menunjukkan Usmani dianggap sebagai kerajaan yang cukup toleran menjadi pelindung dan banyak keluarga Yahudi Eropa yang berangkat menuju arah selatan dan timur Eropa dan selatan dari Eropa Barat dan Tengah. ${ }^{45}$

Pertemuan antar agama di tubuh kerajaan Usmani dimulai sejak pertama terbentuknya kerajaan ini. Ketika kerajaan Usmani berpusat di Edirne atau Adrianopel di awal abad ke 14. Komunitas Yahudi misalnya sudah sejak lama

\footnotetext{
${ }^{43}$ Adian Husaini, Tinjauan. 161

${ }^{44}$ Adian Husaini, Tinjauan. 161-162

${ }^{45}$ Mark Alan Epstein, The Ottoman Jewish Communities and Their Role in the Fifteenth and Sixteenth Centuries, Freiburg: Klaus Schwarz Verlag, 1980), 19-20
} 
berada di sana. Ketika Usmani memasuki Bursa tahun 1324, mereka menemukan komunitas Yahudi menetap. Orang-orang Yahudi menyambut Usmani sebagai penyelamat. Sultan Usman memberikan izin kepada mereka untuk membangun The Etz ha-Hayyim (Tree of Life) Sinagog yang masih tetap terpelihara hingga pertengahan abad ke 20. Komunitas Yahudi lain dari Eropa termasuk Karaites berimigrasi ke Edirne. Hal serupa juga orang-orang Yahudi yang diusir dari Hungaria, Perancis dan Sisilia mengungsi ke wilayah-wilayah Usmani. ${ }^{46}$

Kehidupan yang harmonis antar agama juga diungkap oleh salah satu orang Yahudi dengan mengatakan "Bentangan lautan luas, yang telah dibukakan Tuhan kami dengan rahmat tongkat-Nya. Di sini pintu-pintu kebebasan terbuka lebar bagimu sehingga dapat sepenuhnya menunaikan Yudaisme." ${ }^{47}$ Ini menunjukkan bahwa harmonisasi hubungan antar agama cukup dirasakan oleh para pemeluk agama lain (non-Muslim).

Kerajaan Usmani menjadi tempat perlindungan bagi orang-orang Yahudi yang diusir dari Spanyol tahun 1492 M ketika Sultan Bayazid II menyambut mereka. Di bawah kekuasaan Usmani, non muslim menikmati otonomi komunal dan mereka dijamin keselamatan pribadi dan keamanan properti. Menurut Bernard Lewis, mereka jauh lebih mudah dibanding yang non-kristen atau bahkan Kristen abad pertengahan. ${ }^{48}$

Lebih lanjut, Roger Locker sebagaimana dikutip Adian Husaini, mencatat bahwa kekuatan pasukan Kerajaan Usmani sebagai buah dari sikap toleran mereka terhadap kaum Kristen dan Yahudi. Walaupun bagian besar populasi Kerajaan Usmani adalah Yahudi dan Kristen, mereka tidak tertarik untuk memaksakan mereka pindah ke agama Islam. ${ }^{49}$

Ketika katolik spanyol menguasai wilayah yang sebelumnya dikuasai penguasa Muslim (Spanyol), orang Yahudi dan Muslim Iberia diusir. Pada 31 Maret 1492, Ferdinand dan Isabella mengeluarkan dekrit pengusiran bahwa semua orang Yahudi harus meninggalkan Spanyol pada hari terakhir bulan Juli. Di Istanbul, Sultan Bayazid II, merasa heran atas tindakan kerajaan Spanyol ini karena mengusir secara massal terutama terhadap para profesional seperti dokter-dokter, ilmuwan, pedagang dan guru. ${ }^{50}$ Sublime Porte, istana Turki di Konstantinopel,

\footnotetext{
${ }^{46}$ Zion Zohar, Sephardic \& Mizrahi Jewry, From the Golden Age of Spain to Modern Time, (New York: New York University, 2005), 151

${ }^{47}$ Dikutip dari Adam Lebor, Pergulatan Muslim di Barat: Antara Identitas dan Integrasi, (Bandung: Mizan, 2009), 103

48 Bernard Lewis, The Jews of Islam, (Princeton: Princeton University Press, 1984), . 65

${ }^{49}$ Lihat Adian Husaini, Tinjauan. 162

${ }^{50}$ Adam Lebor, Pergulatan. 103
} 
terbuka untuk menyambut kedatangan banyak orang itu, dan kemudian tumbuh subur di tempat-tempat yang berjauhan seperti Salonika dan Sarajevo, Kairo dan Siprus. ${ }^{51}$ Dari beberapa penjelasan di atas, masuknya Yahudi di wilayah-wilayah Kerajaan usmani secara komunal setelah terjadi pengusiran besar-besaran terhadap mereka oleh Raja Ferdinand dan Isabella setelah berhasil mengalahkan kekuatan Islam terakhir di Granada (kerajaan Bani Ahmar).

Seperti Kerajaan Muslim sebelumnya, Kerajaan Usmani menunjukkan rasa toleransi yang besar komunitas non-Muslim di wilayah kekuasaannya. Mereka dilindungi, diberi kebebasan beragama, dan bebas dari hukuman Syariah.

\section{F. Aturan dalam Sistem Millet}

Millet berasal dari kata Arab untuk "bangsa", yang menunjukkan bahwa Kerajaan Usmani menganggap diri mereka pelindung banyak wilayah. Setiap kelompok agama memiliki millet sendiri, dengan beberapa millet ada di kerajaan. Semua orang Kristen Ortodoks di Kerajaan Usmani dianggap sebagai millet, sedangkan semua orang Yahudi merupakan millet lain. Kata millet berasal dari bahasa Arab 'millah' yang berarti bangsa (nation). Non-muslim diatur oleh kerajaan sebagai kelompok sosio-politik yang semi otonomi di mana para pemimpin agama seperti Ortodoks, Armenia dan Yahudi mewakili komunitasnya masing-masing di hadapan sultan. Mereka juga mengurus kelompoknya sendiri seperti mengatur pernikahan, cerai, warisan dan lembaga sosial lainnya seperti rumah sakit dan sekolah. ${ }^{52}$

Karena keterbatasan pemberlakuan syariat terhadap non-muslim, maka muncullah millet system. Mereka diberi wewenang untuk mengatur masyarakat dengan hukum dan lembaga mereka sendiri. Masing-masing individu atau kelompok menjadi anggota milletnya saja dan mereka berhubungan dengan penguasa millet saja kemudian pemimpin millet bertanggung jawab kepada Sultan dan para pejabatnya terkait permasalahan internalnya, pajak atau kewajibankewajiban lain terhadap kerajaan. ${ }^{53}$

Selama masa ekspansi, Kerajaan Usmani meliputi ragam etnis dan agama. Dalam beberapa catatan historis ditunjukkan bahwa Usmani tidak melakukan intervensi terhadap masalah-masalah non-muslim. Orang-orang Armenia, Georgia

\footnotetext{
51 Adam Lebor, Pergulatan. 103

52 Sinem Adar, Ambiguities of Democratization, Nationalism, Religion and Ethnicity Under AKP Government in Turkey, dalam Julian Go (Ed), Decenting Social Theory (UK: Emerald Book, 2013), 29

53 Shaw, Stanford J., History of the Ottoman Empire and Modern Turkey (Cambridge: Cambridge University, 1976), 151
} 
dan Yunani kebanyakan menghargai atas upaya Usmani yang telah menciptakan kebaikan, kejujuran, kebebasan dan keadilan terhadap semua komunitas di bawah naungan Usmani dengan sistem millet-nya. Sekalipun konsep seperti ini ada sebelum masa Usmani, namun Kerajaan Usmani lebih dihargai karena berhasil melembagakannya. Untuk mengimplementasikan keadilan di tengah-tengah keragaman penduduk, Usmani membagi penduduk ke dalam beberapa komunitas sesuai agama mereka dan mengembangkan sebuah sistem yang didasarkan pada hubungan antar anggota dalam sebuah komunitas yang serupa. Muslim dikelompokkan ke dalam millet al-islam; terlepas dari manapun asalnya baik ras, bahasa ataupun budayanya. Karenanya, Turki, Arab, Kurdi, Albania, Bosnia dan lainnya yang budaya dan bahasa mereka berbeda satu sama lain, dikelompokkan ke dalam satu millet khusus. Sementara yang lainnya seperti orang-orang Ortodoks, Katolik dan Yahudi secara berdampingan. ${ }^{54}$ Orang-orang Kristen memiliki millet sendiri yang dikenal millet-i Nasara sementara kelompok-kelompok di internal Kristen sendiri disebut taife (taifah; bahasa Arab). ${ }^{55}$

Namun dalam perkembangannya, Sistem millet ini tidak mampu bertahan terutama saat Kerajaan Usmani melemah abad 18 dan 19-an dengan berubahnya sistem pemerintahan menjadi bergaya Eropa. Agama menjadi lebih susah mengikuti hukum sekuler, sehingga menyebabkan ketegangan agama dan menjadi sebab genosida orang-orang Armenia selama perang dunia pertama di hari-hari terakhir Kerajaan Usmani. Menurut June Starr, bila sebelumnya pemeluk agama memiliki hak menentukan pemimpinnya sendiri, menunaikan kewajiban agama dan hukum mereka sendiri, maka ketika konsep millet yang diubah menjadi sekuler, mereka kehilangan status millet-nya. Pemimpin mereka hanya menjabat Pemimpin agama saja, sementara pengadilan agama digantikan oleh yang sekuler. 56

\section{Kesimpulan}

Berdasarkan system millet di atas seperti yang diterapkan oleh Usmani terutama masa-masa kejayaannya, menunjukkan bahwa kelangsungan hidup minoritas khususnya kelompok agama bergantung pada toleransi dari kelompok yang berkuasa dan biasanya mayoritas. Millet system diberlakukan sebagai upaya

\footnotetext{
${ }^{54}$ Christoph Marcinkowski, The Islamic World and The West (Kuala Lumpur: LIT \& The Asia-Europe Institute, UM, 2020) 114

${ }^{55}$ Carter V. findley, Turkey, Islam, Nationalism and Modernity (USA: Yale University, 2010), 64-65

${ }^{56}$ June Starr, Laws as Metaphor: From Islamic Courts to the Palace of Justice (Albany:State University of New York Press, 1992), . 16-17
} 
mengatur kelompok atau komunitas yang berdasarkan keyakinan berbeda dengan kerajaan Usmani (Islam). Masing-masing millet seperti Kristen dan Yahudi memiliki hak tanggung jawab sendiri untuk mengatur kelompok atau anggotanya, sementara pemimpin millet ini bertanggung jawab langsung terhadap sultan atau para pejabat yang ditunjuk. Millet ini berjalan selama ratusan tahun hingga kemudian terkikis akibat sekularisasi yang melanda Turki.

\section{Referensi}

Adar, Sinem, Ambiguities of Democratization, Nationalism, Religion and Ethnicity Under AKP Government in Turkey, dalam Julian Go (Ed), Decenting Social Theory (UK: Emerald Book, 2013), 29

an-Na'im, Abdullahi Ahmed, Islam dan Negara Sekuler; Menegosiasikan Masa Depan Syariah, (Bandung: Mizan, 2007)

Black, Antony, The History of Islamic Political Thought: From the Prophet to Present, cet.2 (Edinburgh: Edinburgh University Press, 2011 )

Bulliet, Richard W., dkk, The Earth and Its People: Global History, (Boston: Wadsworth Cengage Learning, 2008)

Collins, Michael \& Matthew A. Price, The Story of Christianity: Menelusuri Jejak Kristianitas (Yogyakarta: Penerbit Kanisius, 2006 )

Creasy, Sir Edward S., The Ottoman Turks; From the Beginning of Their Empire to the Present Time (New York: Henry Holt and Company, 1878)

End, Th. Van Den \& Christiaan de Jonge, Sejarah Perjumpaan Gereja dan Islam, (Yogyakarta: Penerbit Kanisius, 2010)

Epstein, Mark Alan, The Ottoman Jewish Communities and Their Role in the Fifteenth and Sixteenth Centuries, Freiburg: Klaus Schwarz Verlag, 1980)

Findley, Carter V., Turkey, Islam, Nationalism and Modernity (USA: Yale University, 2010)

Fletcher, Richard, Relasi Damai Islam dan Kristen, terj dari The Cross and The Crescent (Tangerang: Pustaka Alvabet, 2009)

Hathaway, Jane, Arab Land Under Ottoman Rule 1516-1800 (Oxon: Routledge, 2020)

Hitti, Philip K., History of The Arabs, (Jakarta: Serambi, 2006)

Husaini, Adian, Piagam Madinah dan Toleransi Beragama. http://www.insistnet.com, 
Husaini, Adian, Tinjauan Historis Konflik Yahudi Kristen Islam, (Jakarta: Gema Insani Press, 2004)

Imber, Collin, The Ottoman Empire 1300-1650; the Structure of Power, (New York: Palgrave MacMillan, 2002)

Knitter, Paul F., Pengantar Teologi Agama-Agama, (Yogyakarta: Penerbit Kanisius, 2008)

Lalu, Yosep, Pr., Menggumuli Makna Hidup dalam Terang Iman Katolik: Seri 4, (Yogyakarta: Penerbit Kanisius, 2010)

Lapidus, Ira M., A History of Islamic Societies, (Cambridge: Cambridge University Press, 2002)

Lebor, Adam, Pergulatan Muslim di Barat: Antara Identitas dan Integrasi, (Bandung: Mizan, 2009)

Lewis, Bernard, The Jews of Islam, (Princeton: Princeton University Press, 1984)

Ma'os, Moshe (Ed), The Meeting of Civilization: Muslim, Christian and Jewish, (Sussex Academic Press, 2009)

Marcinkowski, Christoph, The Islamic World and The West (Kuala Lumpur: LIT \& The Asia-Europe Institute, UM, 2020)

Masters, Bruce, Christian and Jews in the Ottoman Arab World, (Cambridge: Cambridge University Press, 2001)

O'Collin, Gerald \& Edward G. Farrugia, SJ., Kamus Teologi (Yogyakarta: Penerbit Kanisius, 1996)

Sahin, Emrah, Ottoman Institution, Millet System: 1250 to 1920 dalam Andrea (Ed), Cultural Sociology of the Middle East, Asia \& Africa: An Encyclopedia (Thousand Oaks: SAGE Publication Inc, 2012)

Shaw, Stanford J., History of the Ottoman Empire and Modern Turkey (Cambridge: Cambridge University, 1976)

Shaw, Stanford J., History of the Ottoman Empire and Modern Turkey (Cambridge: Cambridge University, 1976)

Starr, June, Laws as Metaphor: From Islamic Courts to the Palace of Justice (Albany:State University of New York Press, 1992), hal. 16-17

Stein, Mark. L., Guarding The Frontier: Ottoman Bordier Forts and Garrison in Europe (London: Tauris Academic Studies, 2007)

Taher, Elza Peldi (Ed), Merayakan Kebebasan Beragama; Bunga Rampai 70 Tahun Djohan Effendi, (Bandung: Mizan, ) 
Hubungan Antar Agama pada Masa Kerajaan Usmani | Lukman Hakim

Zohar, Zion, Sephardic \& Mizrahi Jewry, From the Golden Age of Spain to Modern Time, (New York: New York University, 2005) 